\title{
Medieval Warm Period, Little Ice Age and 20th century temperature variability from Chesapeake Bay
}

\author{
T.M. Cronin ${ }^{\mathrm{a}, *}$, G.S. Dwyer ${ }^{\mathrm{b}}$, T. Kamiya ${ }^{\mathrm{c}}$, S. Schwede ${ }^{\mathrm{a}}$, D.A. Willard ${ }^{\mathrm{a}}$ \\ ${ }^{a}$ National Center, MS 926A, U.S. Geological Survey, Reston, VA 20192, USA \\ ${ }^{\mathrm{b}}$ Earth and Ocean Sciences, Nicholas School of the Environment and Earth Sciences, Duke University, Durham, NC 27708, USA \\ ${ }^{\mathrm{c}}$ Department of Geology, Kanazawa University, Kanazawa, Japan
}

Received 15 July 2001; accepted 29 May 2002

\begin{abstract}
We present paleoclimate evidence for rapid $\left(<100\right.$ years) shifts of $\sim 2-4{ }^{\circ} \mathrm{C}$ in Chesapeake Bay (CB) temperature $\sim 2100,1600,950,650,400$ and 150 years before present (years BP) reconstructed from magnesium/calcium $(\mathrm{Mg} / \mathrm{Ca}$ ) paleothermometry. These include large temperature excursions during the Little Ice Age ( 1400-1900 AD) and the Medieval Warm Period ( 800-1300 AD) possibly related to changes in the strength of North Atlantic thermohaline circulation (THC). Evidence is presented for a long period of sustained regional and North Atlantic-wide warmth with low-amplitude temperature variability between $\sim 450$ and $1000 \mathrm{AD}$. In addition to centennial-scale temperature shifts, the existence of numerous temperature maxima between 2200 and 250 years BP (average $\sim 70$ years) suggests that multi-decadal processes typical of the North Atlantic Oscillation (NAO) are an inherent feature of late Holocene climate. However, late 19th and 20th century temperature extremes in Chesapeake Bay associated with NAO climate variability exceeded those of the prior 2000 years, including the interval $450-1000 \mathrm{AD}$, by $2-3{ }^{\circ} \mathrm{C}$, suggesting anomalous recent behavior of the climate system.

(C) 2002 Elsevier Science B.V. All rights reserved.
\end{abstract}

Keywords: Paleoclimatology; Holocene; Medieval Warm Period; Little Ice Age; 20th Century climate; North Atlantic Oscillation

\section{Introduction}

Observational (Jones et al., 1999), modeling (Santer et al., 1996; Stott et al., 2000; Levitus et al., 2000) and paleoclimate (Mann et al., 1999; Crowley, 2000) studies show that a portion of the secular trend of rising 20th century mean annual temperatures is anthropogenic in origin, reflecting the influence of greenhouse trace gases. These and other studies have

\footnotetext{
* Corresponding author. Tel.: +1-703-648-6363; fax: +1-703648-6953.

E-mail address: tcronin@usgs.gov (T.M. Cronin).
}

led to a consensus that 20th century mean annual Northern Hemisphere temperatures exceed those of the last 1000 years, including the period known as the Medieval Warm Period (MWP) 1000-1300 AD, and cannot be explained solely by solar and volcanic forcing. However, it is still not yet clear to what degree 20th century temperature variability is anomalous in the context of natural centennial and multidecadal climate variability related to changes in the North Atlantic's thermohaline circulation (THC). For example, changes in the hydrological balance in high latitudes have been linked to centennial-scale changes in THC during the Medieval Warm Period and Little 
Ice Age (e.g., Keigwin,1996). Processes such as the North Atlantic Oscillation (NAO), a measure of the normalized sea level pressure difference (SLP) between the Azores and Iceland, is also a major source multi-decadal wintertime Northern Hemispheric climate variability that has been associated with changes in North Atlantic thermohaline circulation (Dickson et al., 1996). Although annually resolved tree ring and ice core records have been successful in reconstructing NAO-associated processes during the Little Ice Age (LIA, Cook et al., 1998; Delworth and Mann, 2000; Cullen et al., 2001), these records deal mainly with changes in SLP and do not cover the important period prior to $1000 \mathrm{AD}$.

In this paper, we present a 2200 -year paleoclimate record of sea-surface temperature (SST) in Chesa-

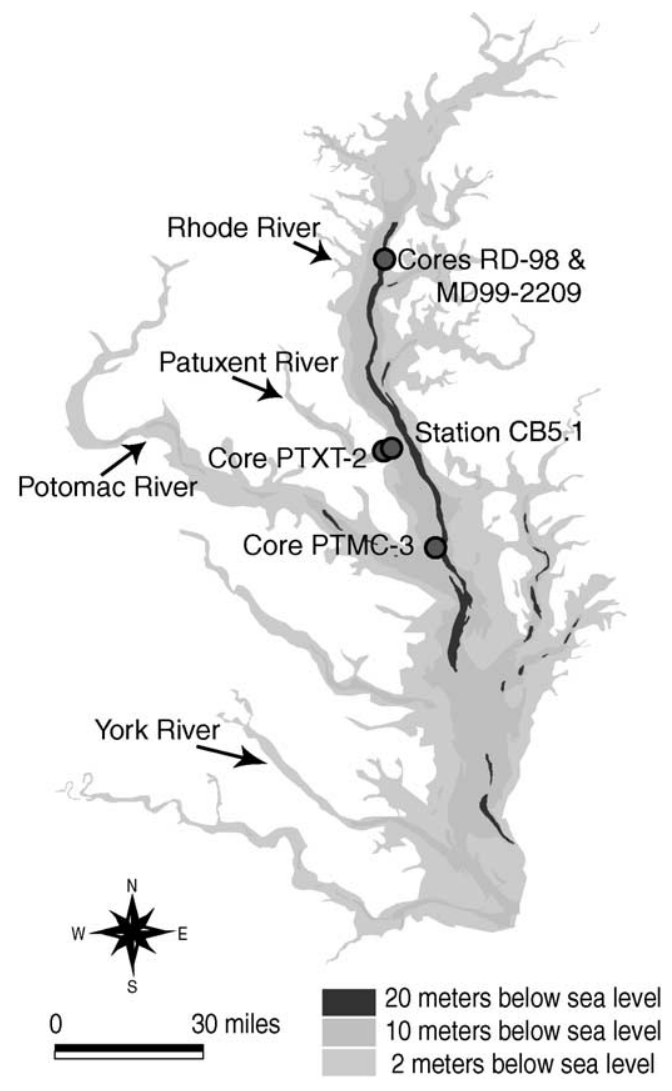

Fig. 1. Location of sediment cores in Chesapeake Bay, a 320-kmlong, $6500 \mathrm{~km}^{2}$ partially mixed estuary that drains a watershed of $166,000 \mathrm{~km}^{2}$. Average depth is $8 \mathrm{~m}$; deep channel is $20-60 \mathrm{~m}$ deep. Sites include RD-98 and MD99-2209 (25 m water depth), PTXT-2 (12 m), PTMC-3 (25 m). peake Bay in the Mid-Atlantic region of the US (Fig. 1), to compare 20th century temperature variability with that during the Medieval Warm Period and Little Ice Age. Chesapeake Bay is ideal for obtaining a long-term paleoclimate record for several reasons. It is located in a region influenced by multi-decadal, NAO-associated SST and air temperature variability (Hurrell, 1996; Kapala et al., 1998). Positive NAO values are associated with strengthened westerlies across the Atlantic and positive temperature anomalies over the western subtropical North Atlantic, as well as much of northern Europe (Hurrell and Van Loon, 1997; Kapala et al., 1998). High sedimentation rates during the last several thousand years $(\sim 1-3$ $\mathrm{cm}$ year $^{-1}$ since $\sim 1800 \mathrm{AD} ; 0.2-1.0 \mathrm{~cm}$ year $^{-1}$ prior to 1800) yield a stratigraphic record, which has a temporal resolution unavailable in most deep-sea records. Further, the bay contains a nearly complete Holocene sedimentary record (Cronin et al., 2000) and thus extends farther back than most tree ring records. Finally, bay sediments contain abundant faunal, floral and geochemical proxies of dissolved oxygen (Karlsen et al., 2000), salinity (Cronin et al., 2000), and terrestrial vegetation (Willard et al., in press), which show that it is sensitive to climate fluctuations.

\section{Chesapeake Bay temperatures}

Chesapeake Bay is an elongate $(\sim 300 \mathrm{~km})$, shallow (average depth $\sim 8.2 \mathrm{~m}$ ), partially mixed estuary with a deep axial channel (10 to $\sim 70 \mathrm{~m}$ ) and a twolayer stratified circulation in which inflowing ocean water underlies lower salinity water influenced by fresh water river discharge (Pritchard, 1967). Largescale circulation in the bay is driven mainly by gravitational processes and to a lesser extent, wind, tides, and topography (Boicourt et al., 1999). Water temperatures are under the combined influence of oceanic source water originating in $\mathrm{S}-\mathrm{SW}$ flowing continental shelf waters with occasional incursions of slope water onto the shelf (Beardsley and Boicourt, 1981) and regional atmospheric temperatures. Seasonal and interannual variability can be examined using the bay instrumental record of temperature, which extends back to 1949 (Chesapeake Bay Program, 2001). There is an annual temperature range 
from $1-2{ }^{\circ} \mathrm{C}$ in winter to $25-26{ }^{\circ} \mathrm{C}$ in summer (Fig. $2 \mathrm{a}$ ), and a thermocline develops in the spring and early summer when surface waters are $\sim 2.0-2.5{ }^{\circ} \mathrm{C}$ warmer than bottom waters depending on the site. For the period 1949-2000, mean monthly temperatures above and below the pycnocline $(\sim 10-13 \mathrm{~m})$ are positively correlated with each other $\left(r^{2}=0.97\right)$.

We also compared Chesapeake Bay monthly temperatures from the deep channel and Comprehensive Ocean and Atmosphere Data (COADs) temperatures from the continental shelf $\left(75.7-76.5^{\circ} \mathrm{W}, 36.5-\right.$ $37.5^{\circ} \mathrm{N}$ ) near the bay mouth for the period 19842000 to examine ocean-bay temperature relationships. These results show that bay SSTs generally reflect regional SST patterns in the adjacent North Atlantic Ocean over monthly and interannual timescales (Fig. 2b). Spring, summer and fall SSTs in the bay average $0.5-1.5^{\circ} \mathrm{C}$ higher than those on the shelf and winter SSTs are typically $\sim 2.7^{\circ} \mathrm{C}$ lower than in the adjacent ocean, reflecting the influence of regional
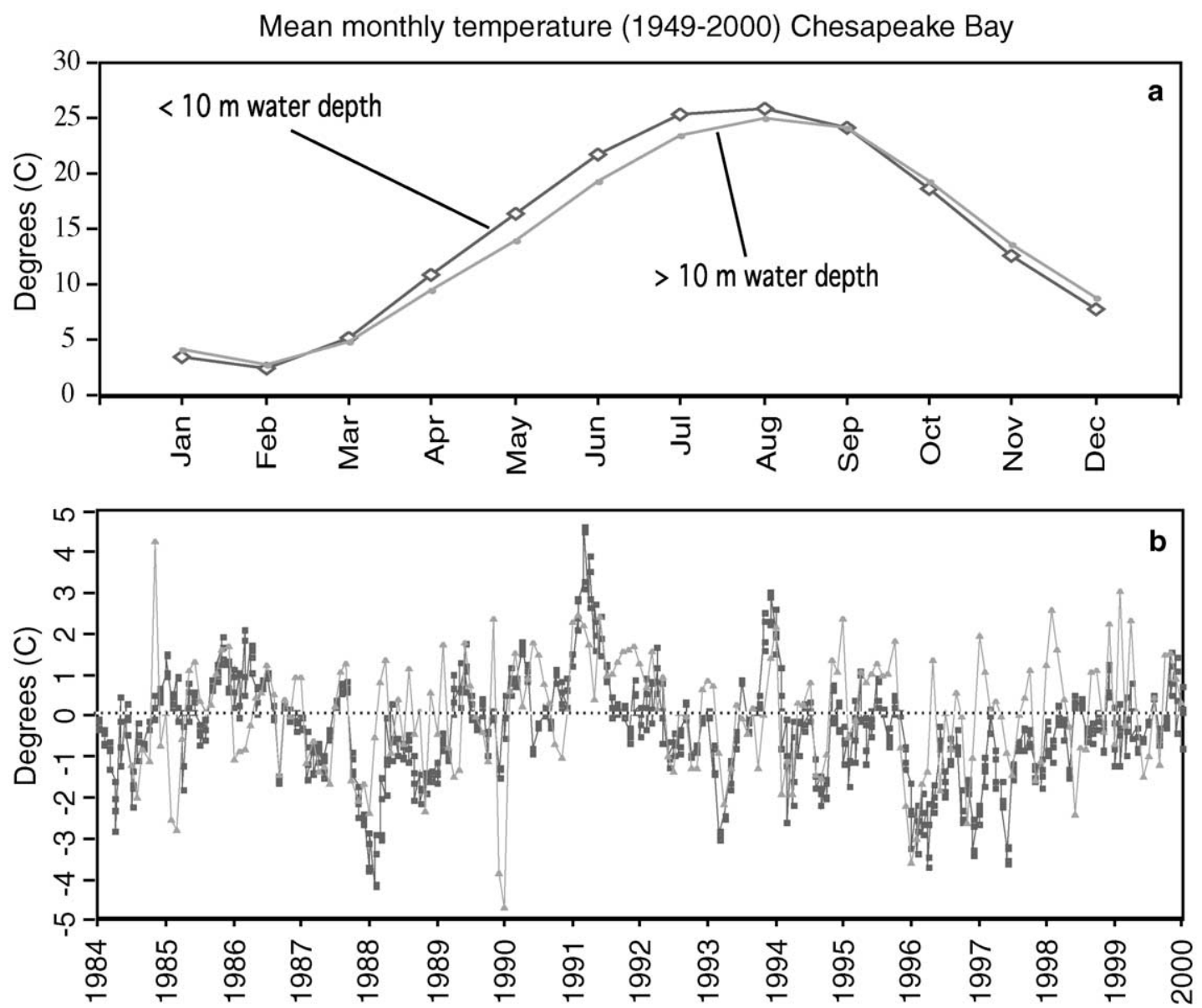

Fig. 2. (a) Mean monthly temperatures $1949-2000$ from $>10 \mathrm{~m}$ and $<10 \mathrm{~m}$ show seasonal thermocline with cooler surface waters in winter through early summer and deeper waters $1-2{ }^{\circ} \mathrm{C}$ cooler in fall. (b) Comparison of Chesapeake Bay (CB station 5.1, >15 m) and COADs (75.7$76.5^{\circ} \mathrm{W}, 36.5-37.5^{\circ} \mathrm{N}$ ) monthly temperature anomalies $1984-1997$. Chesapeake Bay temperatures from monitoring stations for the period 1984-present (http://www.chesapeakebay.net/data) and for the period 1949-1984 from M. Olson, Chesapeake Bay Program (http:// www.chesapeakebay.net/bayprogram/data/wqual $/ \mathrm{htm}$ ). Comparisons of CB temperatures were also made with oceanic SST anomalies from COADs data from 1950-2000 from the NOAA COADs website (http://www.scd.ucar.edu/dss/coads) and from 1984-1997 from Lamont Doherty Earth Observatory (available at http://www.lido.ldeo.columbia.edu). 
atmospheric conditions on bay temperatures. Over decadal timescales, COADs winter and spring records from off the mouth of the bay extending back to 1880 exhibit a pattern of oceanic warming during the $1930-1940$ s, cooling in the 1960s, and warming since the 1970s. This pattern is well-known from prior studies of the North Atlantic climatology (Dickson and Namias, 1976; Deser and Blackmon, 1993) and may be associated with NAO-atmospheric variability and changes in the convective renewal of intermediate and deep water in the Greenland and Labrador Seas (Dickson et al., 1996).

\section{3. $\mathrm{Mg} / \mathrm{Ca}$ temperature calibration}

We reconstructed spring CB SST using the magnesium/calcium $(\mathrm{Mg} / \mathrm{Ca})$ proxy method as a paleothermometer (Chivas et al., 1986). The $\mathrm{Mg} / \mathrm{Ca}$ method is widely used in paleoclimatology and relies on the thermodependence of the uptake of magnesium into the calcitic shells of microfossils (Dwyer et al., 1995; Lear et al., 2000). $\mathrm{Mg} / \mathrm{Ca}$ ratios in ostracode (Crustacea) shells are influenced by the water temperature in which the shell is secreted and the $\mathrm{Mg} / \mathrm{Ca}$ ratio in the water. Whereas $\mathrm{Mg} / \mathrm{Ca}$ ratios may vary in certain estuaries (Dwyer and Cronin, 2001), $\mathrm{Mg} / \mathrm{Ca}$ ratios in Chesapeake Bay mesohaline water of $10-23 \mathrm{ppt}$ (the average salinity at cores sites) is relatively invariant $(\sim 4.6-4.9$ versus 5.1 $\mathrm{mmol} / \mathrm{mol}$ for seawater). Thus, $\mathrm{Mg} / \mathrm{Ca}$ variability in fossil shells can be attributed to changes in water temperature.

To calibrate $\mathrm{Mg} / \mathrm{Ca}$ ratios to water temperature, we measured $\mathrm{Mg} / \mathrm{Ca}$ ratios of shells of three related species of the shallow water genus Loxoconcha using direct current plasma (DCP) emission spectrometry following the cleaning and analytical procedures discussed in Dwyer et al. (1995). Loxoconcha is a cosmopolitan, taxonomically well-known genus whose stratigraphic record extends to the Paleocene. Specimens used in the calibration data set were obtained from three sources (Fig. 3). The first group came from seagrass (Zostera marina) samples taken monthly in 1999 near the mouth of the York River, a tributary located in southern Chesapeake Bay. These samples yielded populations of the epiphytal species Loxoconcha matagordensis (Cronin et al., in press). The second group included specimens of the related species Loxoconcha sp. obtained from the Chesapeake Bay deep channel in June and September 1999 on cruises of the $R / V$ Orion and from the continental shelf off the mouth of the bay. Loxoconcha sp. populations inhabit the inner shelf and polyhaline regions of Atlantic estuaries into which they migrate with inflowing saline Atlantic shelf water. Most downcore specimens used to reconstruct Holocene paleotemperature history were Loxoconcha sp. The third group included Loxoconcha impressa obtained from surface sediments collected on the continental shelf during a large study in the $1960 \mathrm{~s}$ of Atlantic shelf and slope surface sediments and

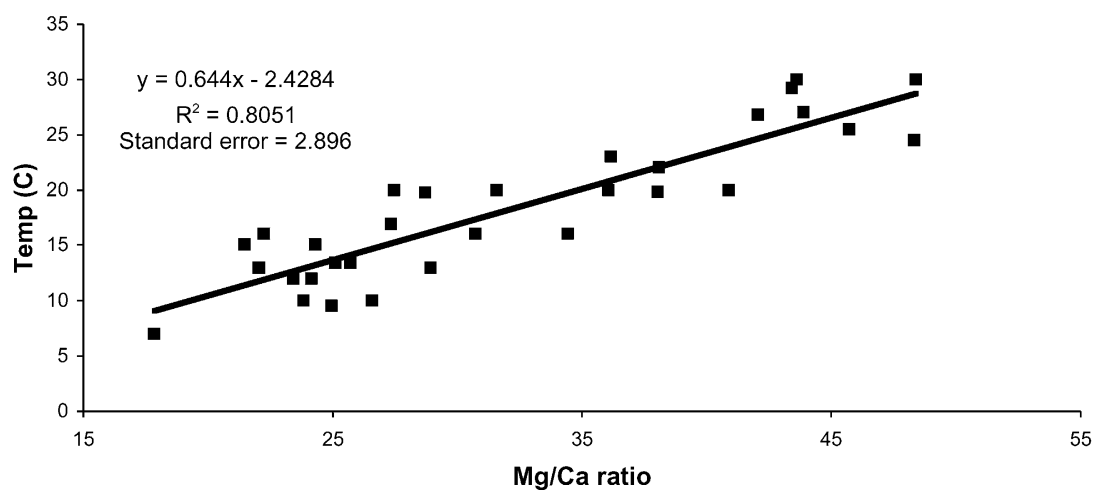

Fig. 3. Loxoconcha $\mathrm{Mg} / \mathrm{Ca}$ temperature regression model $\left(r^{2}=0.805\right)$ for temperature range $7-30{ }^{\circ} \mathrm{C}$, based on living adults from Guinea Marsh and Goodwin Island, York River, main channel of Chesapeake Bay, and the Atlantic Shelf off the eastern United States. See http:// www.geology.er.usgs.gov/eespteam/ches/bayhome.html for data. 
Table 1

Chespeake Bay sediment core location and age models

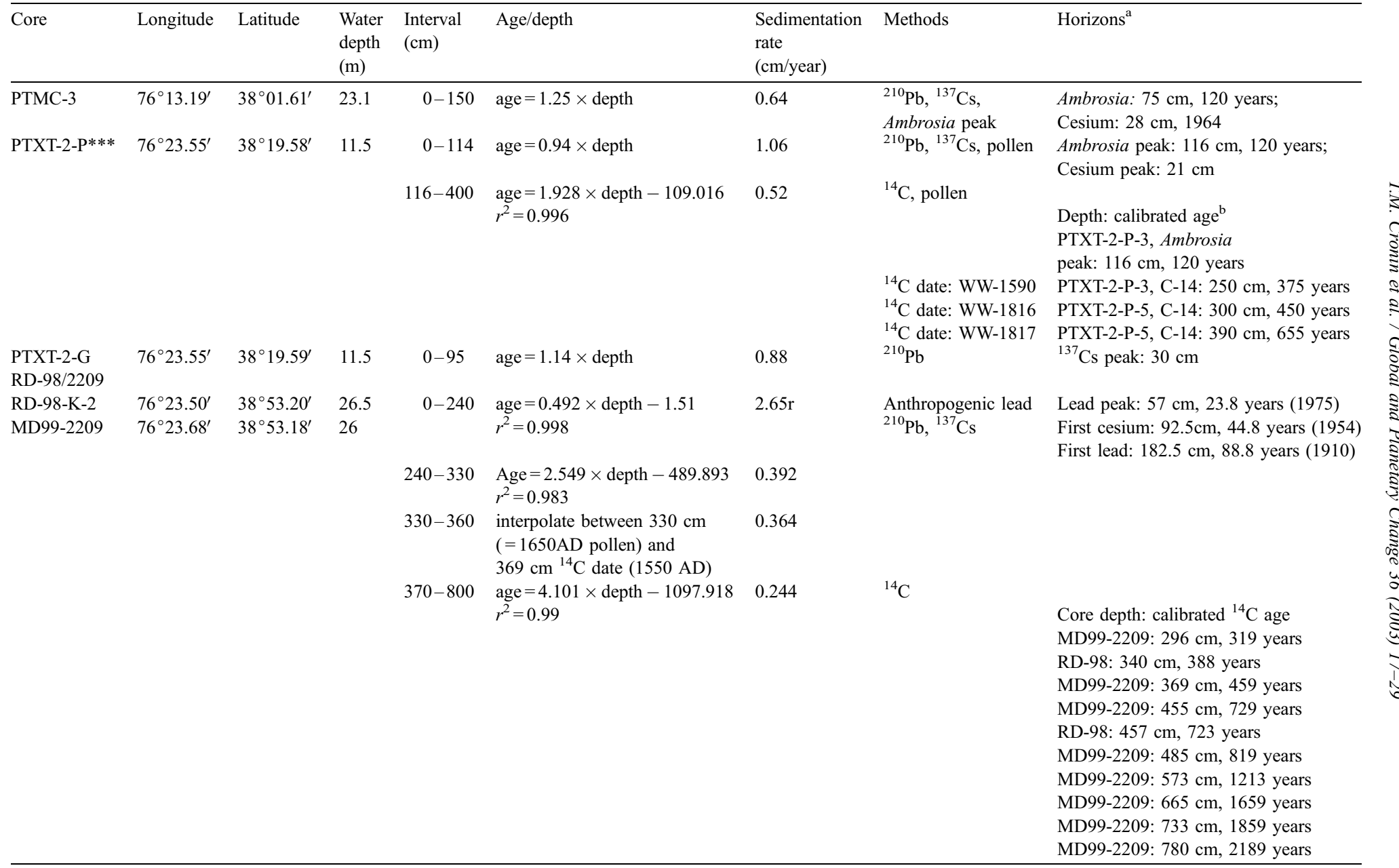

${ }^{* * *}$ Piston core depths corrected by correlation to gravity core lead/cesium horizons by ostracode biostratigraphy anomalous date (WW-1591, 433 years) at $411 \mathrm{~cm}$ omitted

a Source: Willard et al. (in press).

b Years before 1997; calibrated years before 1950 using Stuiver et al. (1998), plus 47 years. 
fauna (Valentine, 1971). Specimens of L. impressa come from 37 to $44^{\circ} \mathrm{N}$ latitude and provide a coolwater end member for the Loxoconcha $\mathrm{Mg} / \mathrm{Ca}$ temperature calibration.

Our ecological studies of populations of $L$. matagordensis living in Chesapeake Bay (Cronin et al., in press) confirm those of previous workers (Kamiya, 1988) and show that the majority of adults secrete their shells during a 5-6-week spring breeding season. However, during this period, water temperatures in the bay rise about $10{ }^{\circ} \mathrm{C}$ and we cannot determine exactly when in the spring adults were secreted. Consequently, some fossil adult shells may represent early spring or summer growth and we use averaging of downcore $\mathrm{Mg} / \mathrm{Ca}$-based paleotemperatures to obtain estimates of mean spring SSTs.

A total of 21 samples covering a temperature range from 7 to $30{ }^{\circ} \mathrm{C}$ were used to obtain the $\mathrm{Mg} / \mathrm{Ca}$ temperature relationship:

$T_{\text {spring }}=0.644 \times \mathrm{Mg} / \mathrm{Ca}-2.428\left(r^{2}=0.81\right)$.

The standard error for this regression model is $\sim 2.9{ }^{\circ} \mathrm{C}$. This $\mathrm{Mg} / \mathrm{Ca}$ temperature relationship based on field collections is supported by studies of subtropical populations of Loxoconcha from Florida Bay (Dwyer and Cronin, 2001) and culturing of specimens grown under controlled temperature and salinity conditions in the laboratory (Dwyer et al., 2002). Our results also suggest that there is little interspecific variability in $\mathrm{Mg} / \mathrm{Ca}$ ratios at least for temperate species of Loxoconcha, although additional studies of shell chemistry for tropical members of the genus might extend the calibration for application in low latitudes.

Chesapeake Bay $\mathrm{Mg} / \mathrm{Ca}$ ratios and station data used in the calibration and downcore paleotemperatures are available from http://www.geology.er.usgs. gov/eespteam/ches/bayhome.html and NOAA's National Geophysical Data Center, World Data Center for Paleoclimatology.

\section{Stratigraphy and chronology}

Four sediment cores taken between 1996 and 2000 were chosen to capture the temperature history of

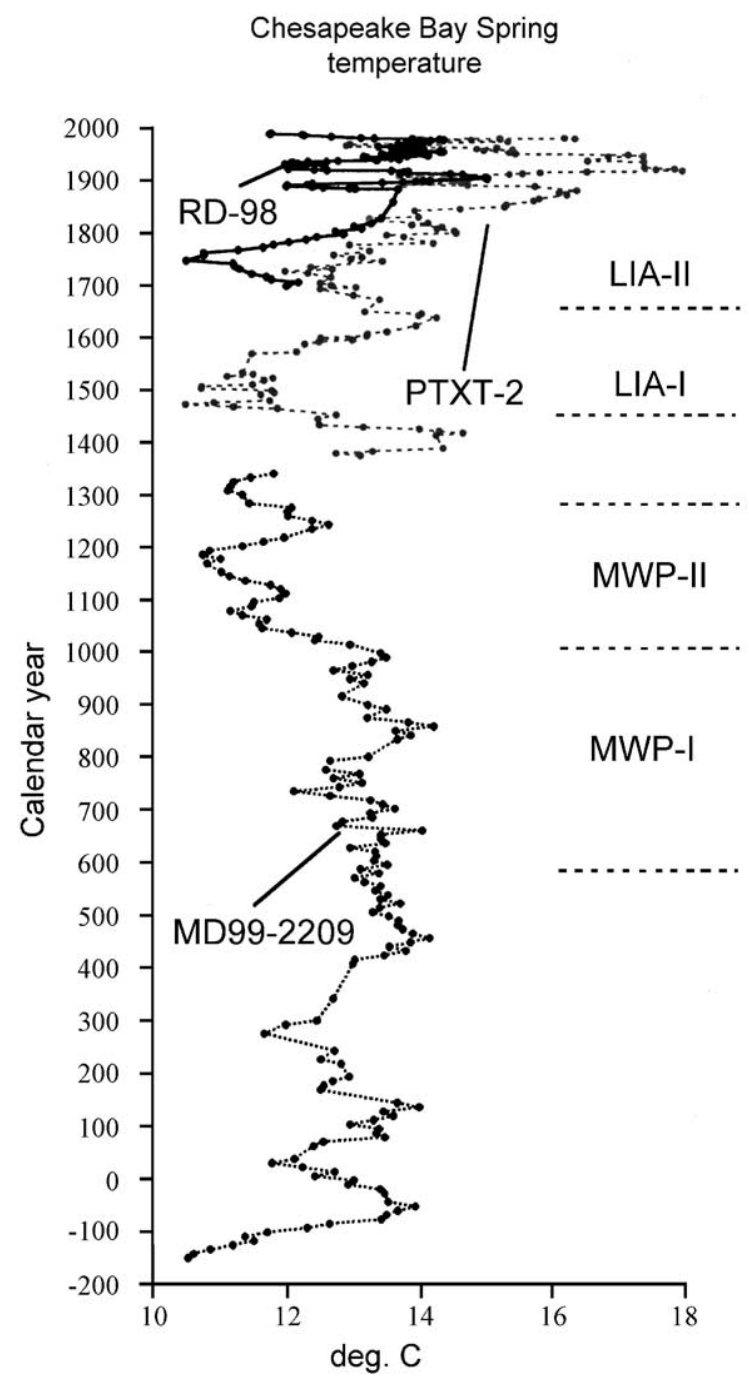

Fig. 4. Curve of 9-point moving average of ostracode $\mathrm{Mg} / \mathrm{Ca}$-based spring temperature estimates for Chesapeake Bay from sediment cores PTXT-2, RD-98 and MD99-2209 for the last 2200 years. Little Ice Age (LIA-I and II) and Medieval Warm Period (MWP-I and II) are labeled. Temperature estimates based on between one and five adult ostracode valves or carapaces measured for $\mathrm{Mg} / \mathrm{Ca}$ ratios using a direct current plasma emission spectrometry using procedures in Dwyer et al. (1995). Mean Mg/Ca values were calculated where more than one shell was measured. Most shells analyzed were Loxoconcha sp. except a few samples where the closely related genus Cytheromorpha was used. Comparison of mean 20th century $\mathrm{Mg} /$ Ca-based temperature estimates for RD/2209 and PTXT-2 sites (see Table 2) shows that deeper waters (site $\mathrm{RD} / 2209$ ) during the last century were on average $\sim 2{ }^{\circ} \mathrm{C}$ cooler than shallower waters (site PTXT-2). This is close to the difference observed in the instrumental record of the bay's modern thermocline, lending further confidence to the $\mathrm{Mg} / \mathrm{Ca}$ method as a predictor of mean spring temperatures. 
Chesapeake Bay at and below the thermocline (Table 1; Fig. 1a) (Cronin et al., 1999). The RD-98-K-2 and Marion-Dufresne MD99-2209 (RD/2209) cores come from a site off the Rhode River in the deep axial channel of the bay (25 m water depth) (Cronin, 2000). The PTMC-3 site $(25 \mathrm{~m})$ comes from the deep channel off the Potomac River farther south of the $\mathrm{RD} / 2209$ site. The PTXT-2 site is located on the western flank of the central bay off the Patuxent River, at a water depth $(12 \mathrm{~m})$ near the modern thermocline.

In core MD99-2209, a series of eight radiocarbon shell dates (Colman et al., 2002) from the interval between 340 and $800 \mathrm{~cm}$ yields an age/depth model with a correlation of $r^{2}=0.98$ and an average $2 \sigma$ range of $\sim 160$ years for ages calibrated using the CALIB 4 program of Stuiver et al. (1998) for marine samples (Table 1). The last two centuries are dated by a combination of lead-210 $\left({ }^{210} \mathrm{~Pb}\right)$, cesium-137 $\left({ }^{137} \mathrm{Cs}\right)$, and pollen biostratigraphy. A sharp increase in $\mathrm{Am}$ brosia (ragweed) pollen caused by 19th century land clearance provides a reliable stratigraphic horizon clearly marking the beginning of the 20th century in all cores (Brush, 1984; Willard et al., in press); the ${ }^{137}$ Cs spike dates the $1963 / 1964$ peak in this radioisotope from nuclear activity (Cronin et al., 1999).

One- to two-centimeter sampling equates to a temporal resolution of 1 per 8 years for MD99-2209 for the period $200 \mathrm{BC}$ to $\sim 1300 \mathrm{AD}(800-350 \mathrm{~cm}$ depth), and 1 per $1-3$ years for RD-98 for the interval 1700 AD until present (310-0 cm depth) (Table 1). The PTXT-2 core provides a paleo-temperature record near the seasonal pycnocline at a sub-decadal reso- lution. Cores RD-98 and PTXT-2 both yield excellent records of the transition from the Little Ice Age into the 20th century. PTMC-3 provides a complementary sub-decadal record of the deep channel farther south for the late 19th and 20th centuries.

\section{Centennial temperature variability during Little Ice Age and Medieval Warm Period}

First, we examined centennial trends in CB spring SST for core PTXT-2 and the spliced record from cores $\mathrm{RD} / 2209$ using a 9-point moving average of the $\mathrm{Mg}$ / Ca-based $T_{\text {est }}$ (Fig. 4). This curve reveals large temperature shifts at 2100, 1600, 950, 650, 400, and 150 years BP separating relatively cool and warm periods each lasting several decades to centuries. We compared mean temperatures using Mann-Whitney-Wilcoxon tests $(p=0.05)$ during five distinct climatic periods (Table 2): the 20th century, the early Medieval Warm Period (MWP-I, 450-900 AD), the conventional Medieval Warm Period (MWP II, 1000-1300 AD), the early Little Ice Age (LIA-I, 1450-1530 AD), and the late Little Ice Age (LIA-II, 1720-1850 AD).

Mean temperatures at site PTXT-2 during both LIA-I and LIA-II were significantly cooler (by $\sim 4.7$ and $2.4{ }^{\circ} \mathrm{C}$, respectively) than those during the 20 th century. Similarly, LIA-II temperatures in the deep channel at site $\mathrm{RD} / 2209$ were significantly cooler than 20th century temperatures. The $\mathrm{CB}$ record of the Medieval Warm Period also exhibits centennial-scale variability, with a large cooling event of $2-3{ }^{\circ} \mathrm{C}$ $\sim 1000-1100$ AD separating MWP-I and MWP-II.

Table 2

Summary of Chesapeake Bay Paleotemperatures from Observations and $\mathrm{Mg} / \mathrm{Ca}$ Proxy

\begin{tabular}{|c|c|c|c|c|c|c|c|c|c|c|c|c|c|c|c|}
\hline \multirow[t]{3}{*}{ Source } & \multirow{2}{*}{\multicolumn{3}{|c|}{$\begin{array}{l}\text { LIA } \\
(1450-1530 \mathrm{AD})\end{array}$}} & \multirow{2}{*}{\multicolumn{3}{|c|}{$\begin{array}{l}\text { LIA } \\
(1720-1850 \mathrm{AD})\end{array}$}} & \multirow{2}{*}{\multicolumn{3}{|c|}{$\begin{array}{l}\text { MWP } \\
\text { (5th-9th centuries) }\end{array}$}} & \multirow{2}{*}{\multicolumn{3}{|c|}{$\begin{array}{l}\text { MWP } \\
(1000-1300 \mathrm{AD})\end{array}$}} & \multicolumn{3}{|l|}{ 20th century } \\
\hline & & & & & & & & & & & & & \multirow{2}{*}{ Temperature } & \multirow[t]{2}{*}{ S.D. } & \multirow[t]{2}{*}{$N$} \\
\hline & Temperature & S.D. & $N$ & Temperature & S.D. & $N$ & Temperature & S.D. & $N$ & Temperature & S.D. & $N$ & & & \\
\hline $\begin{array}{l}\text { Core } \mathrm{RD} / 2209 \\
\mathrm{Mg} / \mathrm{Ca} \text { proxy }\end{array}$ & - & - & - & 11.78 & 1.86 & 19 & 13.52 & 2.32 & 54 & 11.6 & 1.75 & 38 & 13.37 & 2.21 & 69 \\
\hline $\begin{array}{l}\text { Core PTXT-2 } \\
\text { Mg/Ca proxy }\end{array}$ & 10.74 & 3.53 & 16 & 13.04 & 4.2 & 25 & - & - & - & & & & 15.46 & 4.5 & 39 \\
\hline $\begin{array}{l}1949-2000 \\
\quad \text { measured shallow } \\
(<10 \mathrm{~m})\end{array}$ & & & & & & & & & & & & & 16.5 & 1.44 & 47 \\
\hline $\begin{array}{l}1949-2000 \\
\quad \text { measured deep } \\
(>10 \mathrm{~m})\end{array}$ & & & & & & & & & & & & & 14.01 & 1.65 & 43 \\
\hline
\end{tabular}


Mean 20th century $\mathrm{CB}$ temperature at $\mathrm{RD} / 2209$ was significantly warmer than those during the cooler MWP-II ( 1000-1300 AD), but not warmer than mean temperatures during MWP-I (450-900 AD), which experienced two notable temperature maxima $\sim 450$ and $850 \mathrm{AD}$.

The relationship between Chesapeake Bay temperature history and other late Holocene oceanic records reveals important similarities, which, within the limits of age-dating, imply synchronous North Atlantic-wide centennial-scale events. Fig. 5 plots the Chesapeake Bay composite temperature record from cores RD/2209 and PTXT-2 (PTXT-2 temperatures were corrected for bay's thermocline) compared to the oxygen isotope record from the Sargasso Sea (mainly a function of sea-surface temperature) from Keigwin (1996), and the SST record from off West Africa from deMenocal et al. (2000). Together,
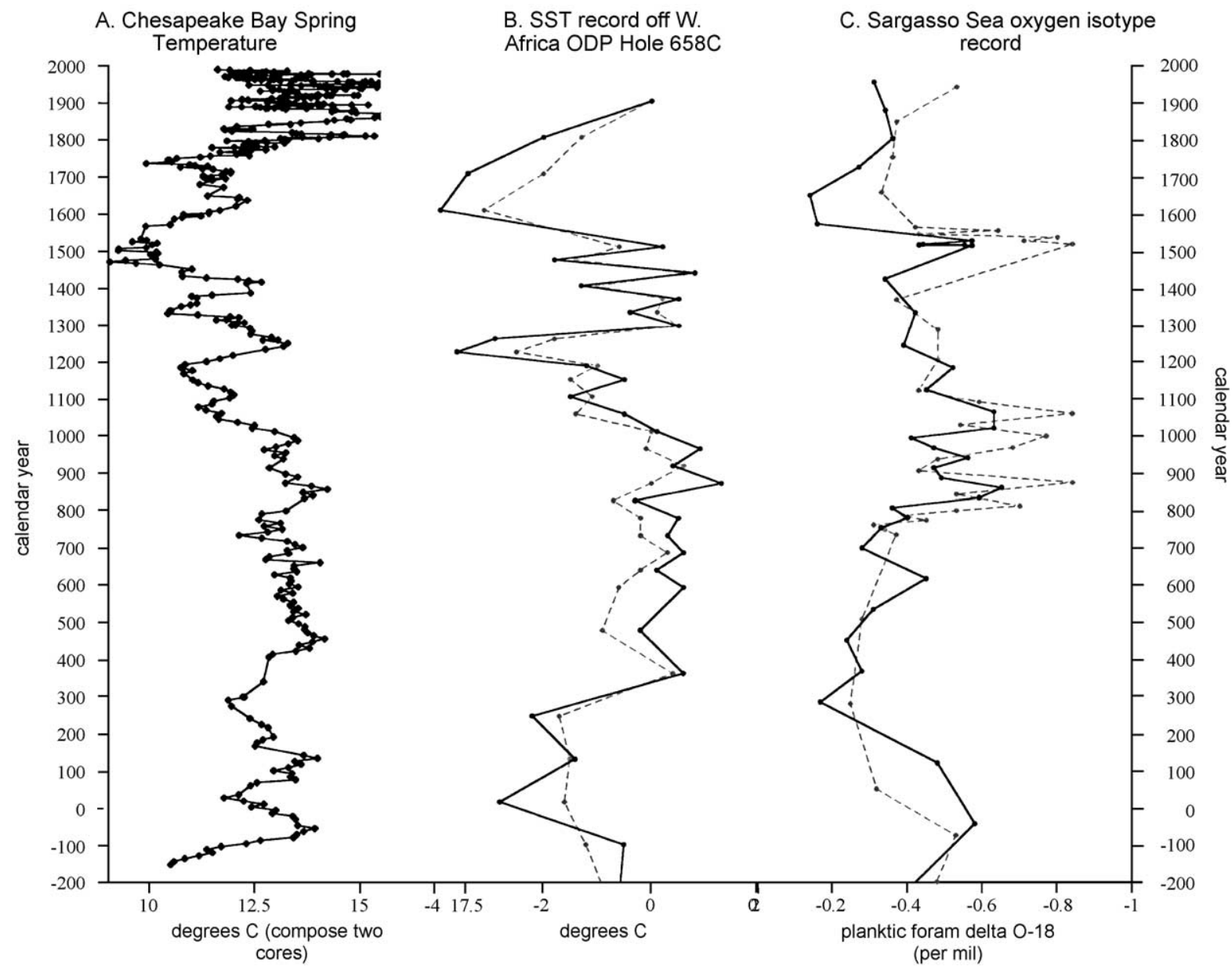

Fig. 5. Chesapeake Bay spring temperature record compared to North Atlantic oceanic records. (A) Composite plot of Chesapeake Bay temperature reconstructed from cores RD, PTXT-2 and PTMC-3. Temperature estimates at the shallow water core site PTXT-2 were corrected by $16 \%$ to account for spring thermocline in bay. The Chesapeake temperature curve is a 9-point moving average, which allows comparison to SST records from off West Africa shown in B from deMenocal et al. (2000) and oxygen isotope record (a function of SST) from Sargasso Sea shown in C from Keigwin (1996). (B) Solid line circles = warm season, dashed line diamonds = cool season SSTs from ODP hole 658. (C) Solid line circles = core HU89-038-BC004-D, dashed line diamonds = core HU89-038-BC-004-A. 
the records indicate generally cool temperatures from $200 \mathrm{BC}$ until about $300 \mathrm{AD}$, a sustained period of relatively high temperatures from $400 \mathrm{AD}$ peaking about 900-1000 AD, progressive cooling until 1150-1200 AD, and a strong temperature minimum between 1450 and 1600 AD. Keigwin (1996) and deMenocal et al. (2000) estimated that oceanic SSTs in the Sargasso Sea and off western Africa during Little Ice Age events were $\sim 1$ to $3{ }^{\circ} \mathrm{C}$ cooler than today, although these records do not have the resolution to reconstruct a detailed LIA SST record. However, Winter et al. (2000) determined that during
LIA-II (1700 and 1815 AD), Caribbean SSTs were $2-4{ }^{\circ} \mathrm{C}$ cooler than present on the basis of coral oxygen isotopic data. The timing of the two LIA cool events in Chesapeake Bay is also remarkably similar to those seen in hemispheric LIA atmospheric temperatures during the mid to late $1400 \mathrm{~s}$ and the 1600 s and the early 1700 s (Mann et al., 1999). In fact, the steep fall in Northern Hemisphere temperatures to a minimum $\sim 1450-1500 \mathrm{AD}$ was postulated by Mann et al. (1999) to represent the start of the LIA. It thus appears that the Chesapeake record captures centennial-scale temperature oscillations

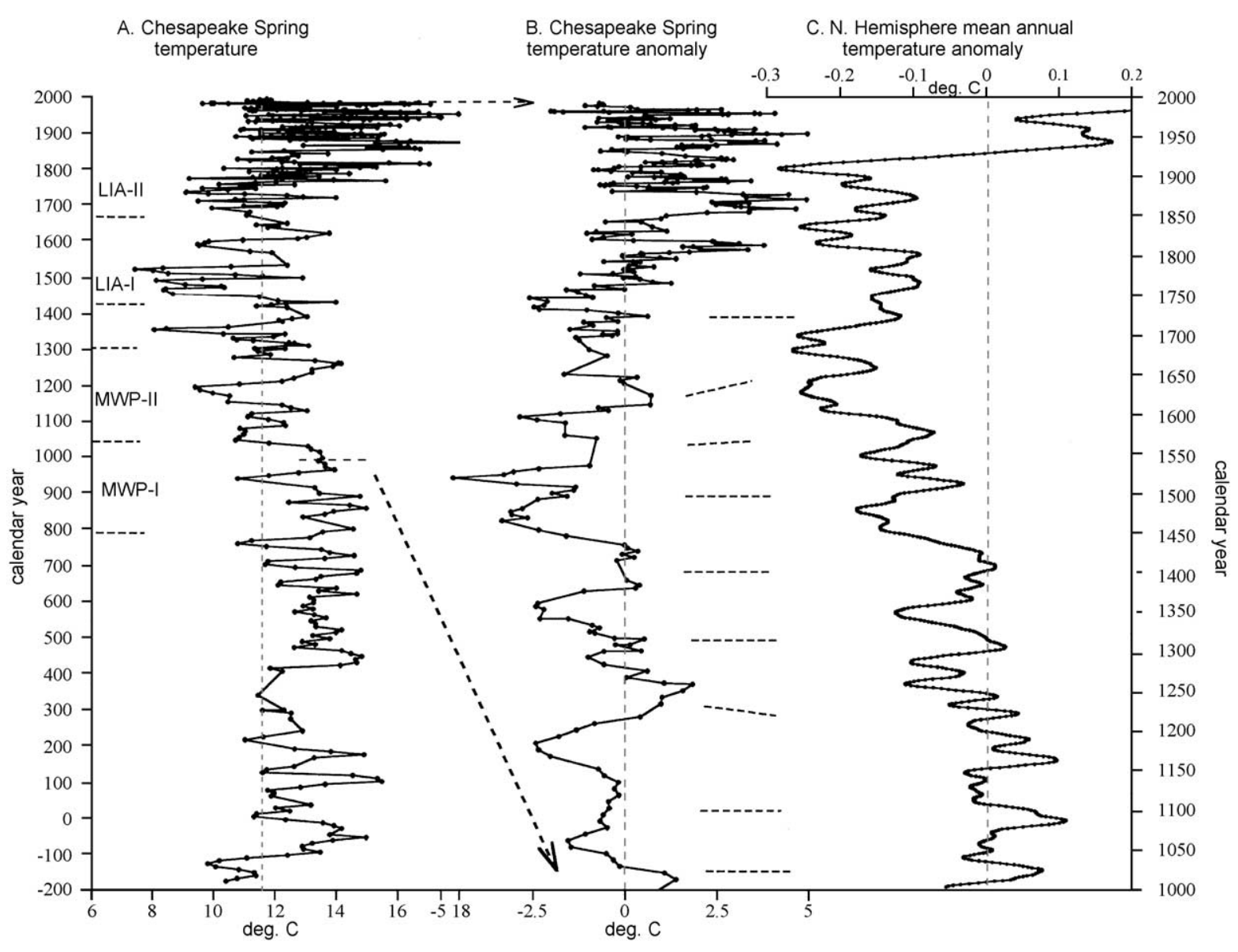

Fig. 6. Comparison of Chesapeake Bay temperature patterns with atmospheric temperatures from the past 1000 years. (A) Chesapeake Bay composite spring temperature from all cores using 3-point smoothing to reveal multi-decadal scale patterns. Vertical dashed line is pre-20th century mean spring temperature $\left(12.3^{\circ} \mathrm{C}\right)$. (B) Chesapeake temperature anomalies $(5$-point smoothing) for only the last 1000 years for comparison to mean annual Northern Hemisphere atmospheric temperature anomalies based on tree ring, ice core and instrumental records reconstructed by Crowley (2000) shown in C. 
characteristic of much of the North Atlantic region, allowing for age uncertainty in the Chesapeake and oceanic records.

\section{Multi-decadal variability}

The CB temperature record also allows us to compare 20th century multi-decadal climate processes to long-term patterns of Northern hemispheric temperatures (Fig. 6). The 3-point smoothing of the 2200-year composite temperature shown on the left side in Fig. 6 reveals numerous $(\sim 25-26)$ brief temperature excursions between $200 \mathrm{BC}$ and $1750 \mathrm{AD}$ with many warm events rising $4-6{ }^{\circ} \mathrm{C}$ above the pre-20th century mean spring temperature of $12.3{ }^{\circ} \mathrm{C}$ (Fig. 6). Although we caution that the exact timing of each warm event cannot be determined, and some extremes may represent shell secretion early or late in the spring season, these multidecadal temperature excursions average out to one every $70-75$ years. It also is noteworthy that temperature maxima during the early MWP-I vary within about a $1{ }^{\circ} \mathrm{C}$ envelope near $14{ }^{\circ} \mathrm{C}$ and that these are $\sim 2-3{ }^{\circ} \mathrm{C}$ cooler than the maxima of the past 200 years. Thus, whereas mean temperatures during MWPI and the 20th century were comparable, the 20th century experienced greater temperature extremes than at any time during the past 2200 years.

The last 1000 years of Chesapeake Bay temperatures are compared in Fig. $6 \mathrm{~B}$ and $\mathrm{C}$ to a smoothed record of mean Northern Hemisphere atmospheric temperature anomaly reconstructed by Crowley (2000) from instrumental and tree ring and ice core proxy data (see also Mann et al., 1999). The Chesapeake SST and atmospheric records differ in type of proxy used $(\mathrm{Mg} / \mathrm{Ca}$ paleothermometry versus tree ring, ice core and instrumental measurements), the seasons (spring versus mean annual temperature), and the temporal resolution (decadal versus annual). Nonetheless, there are many similarities between the two curves. Between 1000 and $1700 \mathrm{AD}$, we observe nine nearly synchronous SST and atmospheric temperature maxima (shown by dashed lines), an early 18 th century rise in temperature, a 19th century LIA minimum and a cooling in the 1960s. Although the unprecedented rise in 20th century mean atmospheric temperatures in Fig. $6 \mathrm{C}$ is not as dramatic in the Chesapeake Bay composite SST record, temperatures from the shallow water Chesapeake core (PTXT-2, Fig. 4) may better represent atmospheric conditions than the deeper part of the bay. More generally, bay temperature maxima since $\sim 1850 \mathrm{AD}$ are the warmest of the past 2000 years is consistent with instrumental oceanic records (Deser and Blackmon, 1993; Levitus et al., 2000).

\section{Discussion}

Our results indicate that the eastern United States is sensitive to large centennial and multi-decadal changes in regional oceanic and atmospheric temperature during the late Holocene. One mechanism causing that could account for periodic centennial-scale temperature shifts of $2-4{ }^{\circ} \mathrm{C}$ that are generally synchronous throughout the North Atlantic Ocean involves changes in the strength of North Atlantic thermohaline circulation. Bond et al. $(1993,1999)$ documented 1500 year \pm 500 year climate cycles related to changes in THC during the last glacial period $(70,000-20,000)$, and Bond et al. (1997) and Bianchi and McCave (1999) discovered similar but dampened cycles during the Holocene interglacial period (10,000-present). These cycles are believed to be partially responsible for Medieval Warm Period warmth (enhanced THC) (Broecker, 2001) and Little Ice Age cooling (weakened THC) in the North Atlantic's subtropical gyre (Keigwin, 1996), the Caribbean (Winter et al., 2000), and throughout the North Atlantic region (deMenocal et al., 2000). In fact, the approximately 1500 years between the inception $\sim 450$ and $1800 \mathrm{AD}$ of two multi-century periods of warm temperatures in Chesapeake Bay suggest that our data may capture the last Holocene 1500-year cycle (see Keigwin, 1996). There is additional evidence from sea level records (e.g., Varekamp and Thomas, 1998) that rapid regional warming $\sim 1800 \mathrm{AD}$ was accompanied by accelerated sea level rise at the end of the Little Ice Age, about 1750-1850 AD, thus preceding large-scale fossil fuel burning. Much of this natural variability may be attributed to low-frequency THC variability, with some contribution from solar and volcanic forcing (i.e., Crowley, 2000).

The ultimate causes of Holocene changes in THC in the North Atlantic region are still unclear. Direct forcing by solar and volcanic processes are respon- 
sible for mean annual atmospheric temperature anomalies years of only +0.2 and $-0.5{ }^{\circ} \mathrm{C}$, respectively, during the last 1000 years (Free and Robock,1999; Crowley, 2000), and are unlikely to explain the magnitude of observed temperature shifts. However, Bond et al. (2001) recently argued that centennial-scale solar variability might initiate late Holocene climate changes, which in turn are amplified by oceanic processes. Rahmstorf (1995) has shown using a general circulation ocean model that even small changes in hydrological cycling, such as changes in freshwater inflow in high latitudes, can lead to changes in thermohaline circulation and temperatures changes of several degrees within only a few years.

Multi-decadal temperature changes observed in CB during the last 2200 years, while smaller in magnitude than centennial shifts, can also be attributed to atmosphere-ocean coupling influencing surface temperatures and thermohaline circulation in the modern North Atlantic Ocean. For example, observed and model simulations of 20th century decadal climate variability off the eastern United States show SST anomalies of 0.5 to $>1{ }^{\circ} \mathrm{C}$ (Kushnir, 1994; Delworth, 1996; Latif, 1998). Dickson et al. (1996) advanced the theory that NAO-related atmospheric forcing influences oceanic convection in the Labrador, Sargasso and Greenland Seas causing multi-decadal-scale changes in the production and export of North Atlantic deep water. Keigwin and Pickart (1999) have suggested that, at least conceptually, both millennial and NAOscale changes in surface and deep slope water currents in the Laurentian Fan involve changes in the strength of Denmark Strait overflow and Labrador Sea deep waters. These processes, which appear to be reflected in 20th century trends in oceanic temperatures including warming over the past 50 years (Levitus et al., 2000), could influence Chesapeake Bay source water originating in the Scotian Shelf region, as well as atmospheric temperatures.

The approximate 70-year spacing of CB temperature maxima, while needing verification in other oceanic records, also lends support to the idea that NAO processes may be responsible for the observed patterns. Delworth and Mann (2000) identified a 70year mode of SST variability in both observation/ proxy data going back 300 years and in simulations using the Geophysical Fluid Dynamics Lab (GFDL) atmosphere-ocean model. Tree ring records from the North Atlantic region (Cook et al., 1998; Cullen et al., 2001), Greenland ice core records (Appenzeller et al., 1998) and Mid-Atlantic precipitation/salinity records (Cronin et al., 2000) all yield evidence for multidecadal atmospheric variability in the North Atlantic region over 60 - to 90 -year periods.

Finally, the evidence for a long period of warmth 450-900 AD, when Chesapeake Bay SSTs were comparable to, but did not exceed mean 20th century conditions, is particularly important in the context of understanding 20th century warmth. Several studies present convincing evidence that 20th century atmospheric temperatures are anomalously warm relative to those covering the past 1000 years (Mann et al., 1999; Crowley, 2000). These 1000-year records have provided the baseline against which the international community has compared the unprecedented 20th century warming (Houghton et al., 2001). However, it appears from Chesapeake Bay and other less detailed North Atlantic oceanic temperature records that much of the period between 1000 and $1900 \mathrm{AD}$ was cool relative to the preceding period $\sim 450-$ $1000 \mathrm{AD}$.

If the Chesapeake record for the period 450-1000 $\mathrm{AD}$ is viewed as a baseline for comparison to 19th and 20th century temperatures in lieu of pre-1000 AD atmospheric records, then the magnitude of recent Chesapeake temperature extremes are larger than those observed even during the relative warmth 1000-1500 years ago. Although this result may be partially due to greater sampling resolution in the last two centuries, it is nonetheless consistent with evidence from other studies suggesting that recent decadal climate variability in the North Atlantic region is extreme relative to long-term patterns and may be in part anthropogenic in origin. For example, Cullen et al. (2001) described anomalous patterns of 20th century sea level pressure reconstructed from 300-year tree ring records for the north Atlantic region. Similarly, modeling studies suggest that early 20th century ocean warming is anomalous and in part anthropogenic in origin (Delworth and Knutson, 2000). The seemingly anomalous behavior of 20th temperature patterns, if confirmed by additional records from high sedimentation rate ocean margin and deep sea regions for the pre-1000 $\mathrm{AD}$ period, suggest human influence and would complicate efforts to predict future climate 
variability associated with multi-decadal climate processes (Griffies and Bryan, 1997).

\section{Acknowledgements}

We are grateful to S. Colman, A. Zimmerman and J. Bratton for RD98 core samples, Y. Balut, E. Michel, R. Younger, R. Kerhin for shipboard assistance, and C. Vann, A. Lavenburg, C. Nytch, B. Berry-Niekirk, K. Moore, for sampling and analyses. H. Dowsett, R. Najjar, L. Wingard, W. Boicourt, J. Buzas and two anonymous reviewers provided helpful comments on the manuscript. We thank T. Crowley for data on 20th century climate trends, S. Worley for COADs data, the World Data Center for Sargasso Sea and West African isotopic and SST data, and M. Olson for Chesapeake Bay temperatures.

\section{References}

Appenzeller, C., Stocker, T.F., Anklin, M., 1998. North Atlantic Oscillation recorded in Greenland ice cores. Science 282, 446-448.

Beardsley, R.C., Boicourt, W.C., 1981. On estuarine and continental-shelf circulation in the middle Atlantic Bight. In: Warren, B.A., Wunsch, C. (Eds.), Evolution of Physical Oceanography, Scientific Survey in Honor of H. Stommel. MIT Press, Cambridge, MA, pp. 198-241.

Bianchi, G.G., McCave, I., 1999. Holocene periodicity in North Atlantic climate and deep-ocean flow south of Iceland. Nature 397, 515-517.

Boicourt, W.C, Kuzmic, M., Hopkins, T.S., 1999. The inland sea: circulation of Chesapeake Bay and the Northern Adriatic. In: Malone, T.C., Malej, A., Harding Jr., L.W., Smodlaka, N., Turner, R.E. (Eds.), Amer. Geophys. Union Coastal and Estuarine. Studies, vol. 55, pp. 81-129.

Bond, G.C., Heinrich, H., Broecker, W., Labeyrie, L., McManus, J., Andrews, J., Huon, S., Jantaschik, R., Clasen, S., Simet, C., Tedesco, K., Klas, M., Bonani, G., Ivy, S., 1993. Evidence for massive discharge of icebergs into the North Atlantic Ocean during the last glacial. Nature 360, 245-249.

Bond, G., Showers, W., Cheseby, M., Lotti, R., Almasi, P., deMenocal, P., Priore, P., Cullen, H., Hadjas, I., Bonani, G., 1997. A pervasive millennial-scale cycle in North Atlantic Holocene and glacial climates. Science 278, 1257-1266.

Bond, G.C., Showers, W., Elliot, M., Evans, M., Lotti, R., Hajdas, I., Bonani, G., Johnson, S., 1999. The North Atlantic 1-2 kyr climate rhythm: relation to Heinrich events, DansgaardOeschger cycles and the Little Ice Age. Am. Geophys. Union Monogr. 112, 35-58.

Bond, G., Kromer, B., Beer, J., Muscheler, R., Evans, M.N., Show- ers, W., Hoffman, S., Lotti-Bond, R., Hajdas, I., Bonani, G., 2001. Persistent solar influence on North Atlantic climate during the Holocene. Science 294, 2130-2136.

Broecker, W.S., 2001. Was the Medieval Warm Period global? Science 291, 1497-1499.

Brush, G., 1984. Stratigraphic evidence of eutrophication in an estuary. Water Resour. Res. 20, 531-541.

Chesapeake Bay Program 2001. (http://www.chesapeakebay.net/ bayprogram/data/wqual $/ \mathrm{htm}$ ).

Chivas, A.R., DeDeckker, P., Shelley, J.M.G., 1986. Magnesium content of non-marine ostracod shells: a new palaeosalinometer and palaeothermometer. Palaeogeogr. Palaeoclimatol. Palaeoecol. 54, 43-61.

Colman, S.M., Baucom, P., Bratton, J.F., Cronin, T.M., McGeehin, J.P., Willard, D., Zimmerman, A.R., Vogt, P.R., 2002. Radiocarbon dating, chronologic framework, and changes in accumulation rates of Holocene estuarine sediments from Chesapeake Bay. Quat. Res. 57, 58-70.

Cook, E., D'Arrigo, R.D., Briffa, K.R., 1998. A reconstruction of the North Atlantic Oscillation using tree-ring chronologies from North America and Europe. Holocene 8, 9-17.

Cronin, T.M. (Ed.), 2000. Initial report on IMAGES V cruise of the Marion-Dufresne to the Chesapeake Bay June 20-22, 1999. USGS Open-File Report 00-306.

Cronin, T.M., Colman, S., Willard, D., Kerhin, R., Holmes, C., Karlsen, A., Ishman, S., Bratton, J., 1999. Interdisciplinary environmental project probes Chesapeake Bay down to the core. EOS, Trans. Am. Geophys. Union 80, 237, 240-241.

Cronin, T.M., Willard, D., Karlsen, A., Ishman, S., Verardo, S., McGeehin, J., Kerhin, R., Holmes, C., Colman, S., Zimmerman, A., 2000. Climatic variability in the eastern United States over the past millennium from Chesapeake Bay sediments. Geology $28,3-6$.

Crowley, T.J., 2000. Causes of climate change over the past 1000 years. Science 289, 270-277.

Cullen, H.M., D’Arrigo, R.D., Cook, E.R., Mann, M.E., 2001. Multiproxy reconstructions of the North Atlantic Oscillation. Paleoceanography 16, 27-39.

Delworth, T.L., 1996. North Atlantic interannual variability in a coupled ocean-atmosphere model. J. Clim. 9, 2356-2375.

Delworth, T.L., Knutson, T.R., 2000. Simulation of early 20th century global warming. Science 287, 2246-2250.

Delworth, T.L., Mann, M., 2000. Observed and simulated multidecadal variability in the Northern Hemisphere. Clim. Dyn. 16, 661-676.

deMenocal, P., Ortiz, J., Guilderson, T., Sarnthein, M., 2000. Coherent high- and low-latitude climate variability during the Holocene warm period. Science 288, 2198-2202.

Deser, C., Blackmon, M.L., 1993. Surface climate variations over the North Atlantic Ocean during winter: 1900-1989. J. Clim. 6, $1743-1753$.

Dickson, R.R., Namias, J., 1976. North American influences on the circulation and climate of the North American sector. Mon. Weather Rev. 104, 1255-1265.

Dickson, R., Lazier, J., Meincke, J., Rhines, P., Swift, J., 1996. Long-term coordinated changes in the convective activity of the North Atlantic. Prog. Oceanogr. 38, 241-295. 
Dwyer, G.S., Cronin, T.M., 2001. Ostracode shell chemistry as a paleosalinity proxy in Florida Bay. In: Wardlaw, B. (Ed.), Bulletins of American Paleontology, vol. 361, pp. 249-276.

Dwyer, G.S., Cronin, T.M., Baker, P.A., Raymo, M.E., Buzas, J., Correge, T., 1995. North Atlantic deepwater temperature change during Late Pliocene and late Quaternary climatic cycles. Science 270, 1347-1351.

Dwyer, G.S., Cronin, T.M., Baker, P.A., 2002. Trace elements in marine ostracodes. In: Holmes, J.A., Chivas, A.R. (Eds.), American Geophysical Union Monograph, vol. 131, pp. 205-225.

Free, M., Robock, A., 1999. Global warming in the context of the Little Ice Age. J. Geophys. Res. 104 (D16), 19057-19070.

Griffies, S.M., Bryan, K., 1997. Predictability of North Atlantic multi-decadal climate variability. Science $275,181-184$.

Hurrell, J.W., 1996. Influence of variations in extratropical wintertime teleconnections on Northern Hemisphere temperature. Geophys. Res. Lett. 23, 665-668.

Hurrell, J.W., Van Loon, H., 1997. Decadal variations in climate associated with the North Atlantic Oscillation. Clim. Change 36, $301-326$.

Houghton, J.T., Ding, Y., Griggs, D.J., Noguer, M., van der Linden, P.J., Xiaosu, D., 2001. Climate Change 2001: The Scientific Basis, Contribution of Working Group I to the Third Assessment Report of the Intergovermental Panel on Climate Change (IPCC). Cambridge Univ. Press, UK, p. 944.

Jones, P.D., New, M., Parker, D.E., Martin, S., Rigor, I.G., 1999. Surface air temperature and its changes over the past 150 years. Rev. Geophys. 37 (2), 173-199.

Kamiya, T., 1988. Contrasting population ecology of two species of Loxoconcha (Ostracoda, Crustacea) in recent Zostera (eelgrass) beds: adaptive differences between phytal and bottom-dwelling species. Micropaleontology 34, 316-331.

Kapala, A., Machel, H., Flohn, H., 1998. Behaviour of the centres of action above the Atlantic since 1881: Part II. Associations with regional climate anomalies. Int. J. Climatol. 188, 23-36.

Karlsen, A.W., Cronin, T.M., Ishman, S.E., Willard, D.A., Holmes, C.W., Marot, M., Kerhin, R., 2000. Historical trends in Chesapeake Bay dissolved oxygen based on benthic foraminifera from sediment cores. Estuaries 23, 488-508.

Keigwin, L., 1996. The Little Ice Age and Medieval Warm Period in the Sargasso Sea. Science 274, 1504-1508.

Keigwin, L., Pickart, R.S., 1999. Slope water current over the Laurentian fan on interannual to millennial time scales. Science 286 , $520-523$.
Kushnir, Y., 1994. Interdecadal variations in the North Atlantic sea surface temperature and associated atmospheric conditions. J. Clim. 7, 141-157.

Latif, M., 1998. Dynamics of interdecadal variability in coupled ocean-atmosphere models. J. Clim. 11, 602-624.

Lear, C.H., Elderfield, H., Wilson, P.A., 2000. Cenozoic deep-sea temperatures and global ice volumes from $\mathrm{Mg} / \mathrm{Ca}$ in benthic foraminiferal calcite. Science 287, 269-273.

Levitus, S., Antonov, J.I., Boyer, T.P., Stephens, C., 2000. Warming of the world ocean. Science 287, 2225-2229.

Mann, M.E., Bradley, R.S., Hughes, M.K., 1999. Northern Hemisphere temperature during the past millennium: inferences, uncertainties, and limitations. Geophys. Res. Lett. 26, 759-762.

Pritchard, D.W., 1967. Observations of circulation in coastal plain estuaries. In: Lauff, G.H. (Ed.), Estuaries. Am. Assoc. Advance Sci., Washington, D.C., pp. 37-44.

Rahmstorf, S., 1995. Bifurcations of the Atlantic thermohaline circulation in response to changes in the hydrological cycle. Nature 378, 145-149.

Santer, B.D., Taylor, K.E., Wigley, T.M.L., Johns, T.C., Jones, P.D., Karoly, D.J, Mitchell, J.F.B., Oort, A.H., Penner, J.E., Ramaswamy, V., Schwarzkopf, M.D., Stouffer, R.J., Tett, S., 1996. A search for human influence on the thermal structure of the atmosphere. Nature 382, 39-46.

Stott, P.A., Tett, S.F.B., Jones, G.S., Allen, M.R., Mitchell, J.F.B., Jenkins, G.J., 2000. External control of 20th century temperature by natural and anthropogenic forcings. Science 290 , 2133-2137.

Stuiver, M., Reimer, P.J., Braziunas, T.F., 1998. High-precision radiocarbon age calibration for terrestrial and marine samples. Radiocarbon 40, 1127-1151.

Valentine, P.C., 1971. Climatic implication of a late Pleistocene ostracode assemblage from southeastern Virginia. U. S. Geol. Surv. Prof. Pap. 683-D, D1-D28.

Varekamp, J.C., Thomas, E., 1998. Climate change and the rise and fall of sea level over the millennium. EOS, Trans. Am. Geophys. Union 69, 73-75.

Willard, D.A., Cronin, T.M., Verardo, S., in press. Late Holocene climate and ecosystem variability from Chesapeake Bay sediment cores. Holocene. The Holocene 13.

Winter, A., Ishioroshi, H., Watanabe, T., Oba, T., Christy, J., 2000. Caribbean sea surface temperatures: two-to-three degrees cooler than present during the Little Ice Age. Geophys. Res. Lett. 27, $3365-3368$. 